\title{
TRADES UNIONISM
}

For several years our country has been subjected to uncertainty and disturbance on the part of industrial workers to an unprecedented and very alarming extent. The whole country has suffered and a large part of the people have been directly affected thereby. This situation has culminated in the outbreaks or strikes of the past year, which have tied up many important industries. Naturally, the greatest interest has arisen in the means, the organizations, by which this situation has been effected. These organizations are the trades unions, and what they are, what their ains are, and what means are employed to realize these aims, are questions of deepest national import.

Trades unions are combinations or associations of workmen of the various trades for the mutual support and advancement of what the association considers its best interest. For their origin we must look back at least to the "guilds" of the Middle Ages-before the introduction of the factory system or of any but the crudest mechanical devices. The industrial relations were of the simplest nature, the "business" was run in a patriarchal way. Gradually the head of the business became a merchant and always further removed from the ranks of the artisans. Disputes soon arose as to the manner of doing work or concerning the pay therefor, and in 1776 we find Adam Smith writing, as of a familiar thing, of combinations being formed by workmen to collectively force up the price of their labor. Such combinations were regarded in England as late as I824 as "conspiracies in restraint of trade and illegal." As a result of repressive laws, a fraternal feeling sprang up, heavy oaths and a policy of secrecy were adopted, beneficial features, such as sick, accident, superannuation, and death benefits, were instituted, and defence funds founded. Many, if not all, of these features still persist, although the outward forms of the bonds have been eliminated. Through political agitation, largely induced by the unions, factory acts, mines acts, and employer's liability acts, have been passed in all civilized countries, nearly all of which have been highly favorable to the wage-earning class. The State of Pennsylvania in 1872 recognized the right of members of labor organizations to refuse to work under regulations contrary to the rules of the organization, but further provided that

[427] 
"nothing shall prevent the prosecution and punishment, under existing laws, of any person or persons who shall in any way hinder another who desires to labor for his employer from so doing."

The members of trades unions in this country are said now to number altogether about one and one-half millions. The growth in membership and strength has been especially rapid during the last four years, a fact mainly due to the opportunity offered for the success of labor propaganda by the phenomenal industrial activity of our country. Many of these organizations are either independent or local. Others have a parent organization, a general directing body over all the local organizations, such as the American Federation of Labor. Generally speaking, the fundamental ain or object of all these organizations is to obtain increased wages for a decreased number of hours of work. Secondarily, but scarcely less important in the eyes of many members of the unions, they attempt to obtain recognition of the union and the restriction of output.

The first of these aims is legitimate enough, and the success which has crowned the efforts of certain unions, particularly of recent years in this regard, is their chief claim to consideration from the wage-earner. For example, consider the situation in two of our tracles to-day-the bricklayers and the blacksmiths. The second requires a higher order of intelligence and skill, it requires continual learning and a much longer period before the attainment of ordinary proficiency, it is much harder work and involves greater danger of injury, the conditions under which the work is done are more disagreeable. The bricklayer will say that he can work only in fair weather, and that his wages must, therefore, be high enough to compensate him for the time when he is idle. This is no longer true, for cement is used in place of common mortar, so that operations can be carried on in freezing weather. The men are frequently protected by temporary enclosures, lighted and even heated. Yet bricklayers are getting five dollars for eight hours' work, while blacksmiths are fortunate if they obtain three dollars for ten hours' work. You do not find this difference between members of varying efficiency in one trade, for the union specifies that all shall receive the same rate, but the difference is between the two trades and greatly in favor of that of lower order. This is a most forceful illustration of the advantage to labor of a strong organization and of collective bargaining.

The wage per hour may fluctuate to a certain extent with the [428] 
price of food and the general condition of the country, but a reduction of the working hours once obtained remains. The reduction has been made within a few decades from fifteen to twelve, from twelve to ten, and now all government and much private work is on an eight-hour schedule. It is probable, and seems to be the tendency, that this will become general wherever practical to complete the day's work in such a time. For this reduction of hours the working classes have to thank the trades unions.

Recognition is not always insisted upon by the union. Where it is granted it means that the employer agrees to employ and discharge union men through the union officials, to grade his employees (and incidentally their wages) according to the standards of the union, to subject his shop discipline to union rules, frequently to buy only unionized supplies for his business, and to employ only members of the union. Sooner or later these conditions and their logical extensions become intolerable, they sometimes even conflict with the labor laws, and a rupture follows.

Restriction of production is not generally admitted by labor leaders to be one of the tenets of their policy. Conclusive evidence, however, can be furnished to prove that the so-called "ca' canny" (go easy) policy of British trade unions is rapidly gaining a foothold in this country, and, unless checked, will work dire mischief for the entire land. No more demoralizing policy for the workers can be conceived than this. There is no greater fallacy than the belief that there is a fixed or limited amount of work to be done in the world, the husbanding of which will redound to the ultimate benefit of the wage-earner. The recent decline of the British manufactures may be attributed more largely to this mistaken policy than to any other single cause. A writer in the London Times has shown, in a series of articles on "The Crisis in British Industries." that the "ca' canny" system has reduced the product of an English trade unionist's work to a point where his labor, once the most profitable in the world, now frequently nets a loss to his employer. It is stated that thirty years ago an English bricklayer would lay r,200 bricks in a day, now the maximum allowed by the union is four hundred. Nor is this the only means adopted to effect limitation, for the British unions have refused to allow the introduction of improved machinery, they have adopted stringent rules limiting the hours and rate of its operation, and, when these measures were found 
not to be efficacious, have deliberately planned its injury or destruction. In some shops, after the failure of the above means, the disappointed men have committed serious crimes by malicious and persistent interference with the operation through the changing of feeds and speeds, "racking" by reckless running, "forgetting" to lubricate, or the breaking and "losing" of small parts. The defence of the limitation of output on the part of certain unions is that without it the normally average worker would be forced to come up to the standard set by the strongest and most skillful, and in this way become wom out and useless before his time. If this were proven true, or even well substantiated, it would merit attention and become a proper subject of governmental control. The charge, however, is baseless. No employer expects all men to be equally industrious and skillful, nor to drive his men beyond their strength, but he naturally desires to buy labor just as he purchases any other commodity, that is, according to quality and quantity; he does not wish to pay the same rate of wage to the least efficient man as he does to the most efficient. Yet this is, in effect, what the trade union demands.

Piece-work and premium systems have been devised for the purpose of stimulating industry and rewarding efficiency. The premium system is regarded by many students of wage adjustment as the most equitable plan of wage payment that has yet been devised. Assuming that a fair base price for a given job has been fixed upon in advance as satisfactory to employer and employee (being adapted to the earning capacity of the average worker), to which is added a premitum for an increase of output by the more diligent and skillful operatives, we have a system which pays a fair "living" wage to the average worker and then encourages him by a substantial inducement to excel. This cannot be contorted into a method of forcing the men into activity beyond their strength. It would seem that if the unions desired to elevate the standard of efficiency of their men the universal establishment of such a system would be their first demand instear of an object of their abhorrence.

Recently a strike occurred in a machine shop, against the wishes of the employees, by the order of the union to which they belonged. to compel the company to abolish the premium system, and, in this way, to reduce the earnings of their men. The premium system had been in use for two years where it was giving satisfaction to the company and the men. and it was reported that the official representatives of 
the union refused to submit the matters in dispute to a disinterested board of conciliation. Labor unions which embrace this policy of restriction of output as a means of maintaining the status of their trade should reflect that it offers the very greatest stimulus to the invention and perfection of automatic machines which dispense more and more with skilled hand-workers and skilled attendants. In the foundry, for example, molding machines operated by unskilled laborers or even boys are fast clisplacing skilled molders in the lighter classes of work and their scope is being continually enlarged.

As to the means of realizing the aims of trades unions, the first is agitation followed by a presentation to the employers of the case of the employees. Sometimes an attempt is made to argue the case to a settlement, more generally an ultimatum is deliveredthe alternative of compliance is a general tie up of the shops by a strike of the union labor. If this is not effective because of the ability to operate without union labor, every pressure of persuasion, ostracism, diversion and opprobrium, and finally violent force is brought to bear upon those willing to work for the firm under established conditions. This is brought to bear not only upon the worker, but also upon his wife and children and sometimes more distant relatives, and by not only the strikers but their sympathizers and those dependent upon or at the mercy of the strikers, such as grocerymen and other suppliers. Every effort is made to interfere with and cripple the employer, $i$. $e$., the "boycott" against him and against all who support him; or the "sympathetic strike" by the members of other tunions is resorted to in order to tie up other business houses and thus bring outside commercial pressure to bear upon the resisting employer. These are crude, back-handed weapons which have rarely proven effective.

The control over the unions, or the leadership of them, is in the hands of men elected from amongst their own ranks and often selected without regard to the possession of those qualities which are generally considered necessary to a wise counsellor or an able leader. These men are usually poor workers, or at best mediocre. They are selected because they have the persuasive or the blatant tongue. In an excited meeting, by the exhibition of a spirit of bravado, they carry their fellows away from the conservative and moderate and obtain the leadership. They now consider themselves above their trade and either leave it or become so intolerable in their attitude 
as to compel their discharge. The ordinary routine of their new position, the desire to convert all the non-union men about them or some other cause may lead to such neglect of work that the employer finds it necessary to be rid of them. They and their supporters consider that it is a blow aimed at the union. The result is frequently bad blood. At any rate, they will now be supported on a salary from the union, and to keep the men interested they must be active. This activity usually takes the form of agitation for a strike against this or that "wrong." The union so led is generally largely made up of men of inferior skill, and it is for this reason that they do not succeed well, are poorer paid than some others, have to be followed up in their work by the foreman and are generally fruit for discontent. Such a union is always having trouble. In sharp contrast with it is such a union as the Brotherhood of Locomotive Engineers, the architype of all that is best in unionism and an example of what intelligent and careful leadership may do for organized labor. Its strifes have been few, and none at all in recent years; it is rich, it is powerful, it is recognized as a power for good. It strives honestly to raise the standard of efficiency of its men, and the card of the brotherhood is regarded as a strong recommendation of efficiency and good character by railroad superintendents and master mechanics the country over.

Radical leadership has made most of our unions unsuccessful and given them a name for bad faith and for mean and petty action. There is reason for hope in the improvement during the past few years in the leadership of some that gradually all will select either their own most fit representatives or that labor leaders will be trained to their calling as are lawyers or generals. When they do profit by the example of the most successful, much of the present prejudice against them will be forgotten, and a man with the union card will have a certificate of efficiency and good character, for none other will be eligible. When these are the effects of unionism upon labor, the emplover will welcome and encourage the movement as one of the modern agencies for doing the world's work expeditiously and economically.

Philadelphia.

Alexander E. Outerbridge, Jr. 